\title{
Rogan steps down as USPTO director
}
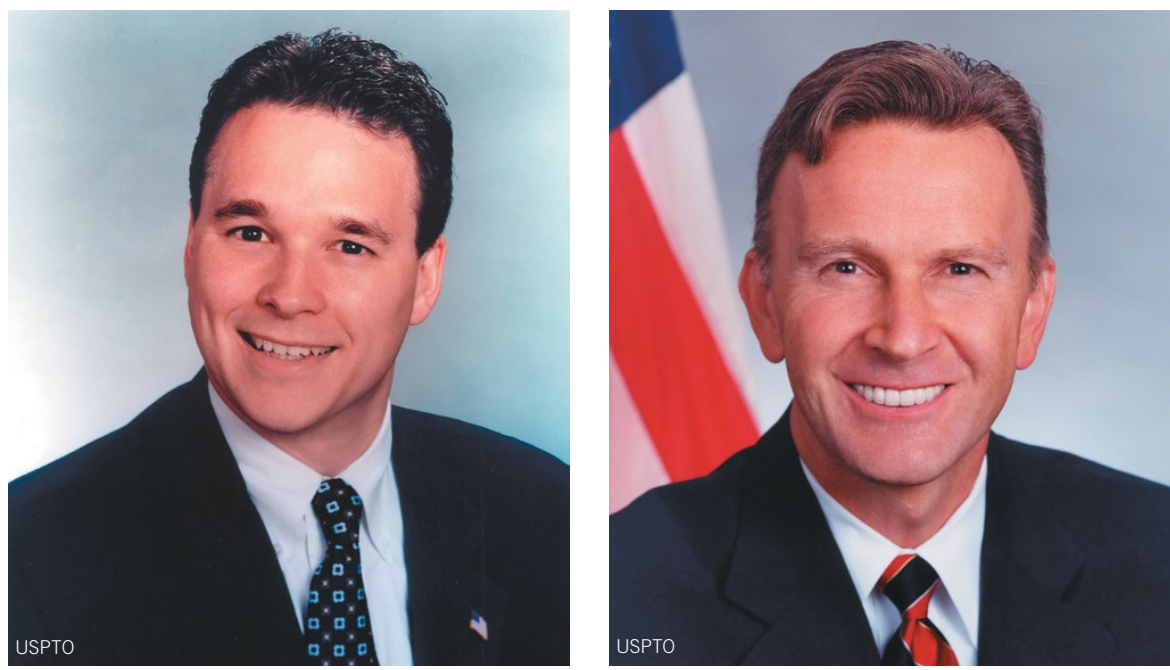

Jon Dudas (left) will be picking up where James Rogan left off as director of the US Patent and Trademark Office.

James Rogan stepped down from his post as director of the US Patent and Trademark Office (USPTO; Washington, DC, USA) on January 9. Although intellectual property experts praise Rogan for introducing initiatives to modernize the administration of the patent system, his successor must contend with an agency that remains underfunded and overworked.

Rogan, director since December 2001, will be remembered best for launching a five-year 21st Century Strategic Plan to overhaul the US patent system (Nat. Biotechnol. 21, 345-346, 2003). Key features of the plan, which has yet to be completely implemented, include acceleration of processing time by switching from paper to electronic filing of applications, a new funding structure for filing applications and streamlining the patent examination process. The patent filing process is now much smoother and more efficient, says Todd Garabedian, a partner in the law firm of Wiggin \& Dana LLP (Hartford, CT, USA). "Timelines are more adhered to and the whole process is faster. [Rogan] has made the office more user-friendly and customer-oriented," says Garabedian.

But there is still much work to be done by Rogan's interim replacement, Jon Dudas, former deputy director of the USPTO. Implementation of the Strategic Plan cannot be done without more money, says Bruce Lehman, former director of the USPTO and current president of the International Intellectual Property
Institute, an international development organization and think tank. "The problem is the growing backlog of applications compared to the resources given by Congress," says Lehman.

If the practice of fee diversion ends, then patent fees must be increased and the surcharge has to go into the general treasury to make up for funds that are lost. Congress cannot give back money it has come to rely on, particularly in the midst of a budget deficit.

Lila Feisee, director for intellectual property at the Biotechnology Industry Organization (Washington, DC, USA), blames the USPTO's financing difficulties on the process of fee diversion. "In the past ten years, about $\$ 650$ million has been diverted from the USPTO [to subsidize other federal programs]," says Feisee. She backs an anti-diversion measure that is contained in The United States Patent and Trademark Fee Modernization Act of 2003 (PTFMA), which has yet to be passed in the US House of Representatives or the Senate. "As long as there is no diversion, we don't have a problem with a fee increase. But if they take the anti-diversion measure out, we would have very major concerns," says Feisee.

But Lehman says if the practice of fee diversion ends, then patent fees must be increased and the surcharge has to go into the general treasury to make up for funds that are lost. Congress cannot give back money it has come to rely on, particularly in the midst of a budget deficit, he says.

The PTFMA would restructure application fees to address the USPTO's money shortage and to fund other aspects of Rogan's Strategic Plan. Thomas Kowalski, a partner in the law firm of Frommer Lawrence \& Haug LLP (New York), says some of these restructurings are impractical and will harm biotech applicants. For example, if the PTFMA passes in its current form then the USPTO would charge more for longer applications. "The fees could become astronomical based on the number of claims that are typically advanced [in a biotech patent]," says Kowalski. But Lehman says the fees are not unreasonable: "Even with a modest increase, the [USPTO's] patent fees [that generally range from $\$ 385$ to $\$ 2,000$ ] are still the lowest in the world for a comparable sized office."

Another key concern for biotechs is the USPTO's current restriction practice, which forces individual claimed inventions to be divided and filed as multiple patent applications. This means more filing fees for biotechnology patents, which usually have several components. This is very costly for the biotechnology industry, says Feisee.

Dudas must also contend with an overworked staff, says Kowalski. "If you give [an examiner] anywhere from 19 hours or less to look at a patent application and expect them to search thoroughly, that is going to be prohibitive," he says. "The next director has to address the issue of bad patents coming up."

The USPTO has to also exert more leadership in policy issues such as copyright and defense of international and domestic patent rights, says Lehman, who thinks Dudas is perfect for the job. Dudas has previously served as a Deputy General Counsel and Staff Director for the House Judiciary Committee and as a Counsel to the Subcommittee on Courts and Intellectual Property. "Given the fact that the solution to the PTO's problems is to work with Congress, I can't think of anybody who is better situated to deal with that than Jon Dudas," says Lehman.

Aparna Surendran, New York 